\title{
AKTIVITAS MUI DALAM PERKEMBANGAN KEHIDUPAN KEAGAMAAN DI SURAKARTA TAHUN 1975-2015
}

\author{
Hasan Maftuh \\ Mahasiswa Pascasarjana UIN Sunan Kalijaga Yogyakarta \\ Hasanmaftuh220@gmail.com
}

\begin{abstract}
This research was developed using the approach of social history that refers to events or socialreligious reality in society and aims to clarify the role of the Assembly of the Ulama Indonesia (MUI) of Surakarta in responding to the change or the development of the social-religious life in community. The results of this research demonstrates that (1) the Assembly of Indonesia of Surakarta Scholars played full, in the Islamic community especially. For example, they provide advice, counsel and fatwa guidance asked or not. (2) in the social reality, they respond to the social conflict. The responses enacted by the scholars are presented into three terms, among others; attempting to be a pioneer of the peace at the time of the riots, giving social advocacy in form of action and being a mediator when conflicts arose disagreements.
\end{abstract}

Keywords: $\quad$ MUI, Life and Religious

\begin{abstract}
Abstrak
Penelitian ini dikembangkan dengan menggunakan pendekatan sejarah sosial yang merujuk kepada peristiwa atau realitas sosial-keagamaan di masyarakat dan bertujuan untuk memperjelas peran Majelis Ulama Indonesia (MUI) Surakarta dalam merespons perubahan atau perkembangan kehidupan sosial-keagamaan di masyarakat. Hasil penelitian ini menujukan bahwa (1) Majelis Ulama Indonesia Surakarta berperan penuh terutama dalam lingkungan masyarakat Islam. Misalnya memberikan anjuran, nasehat dan bimbingan fatwa baik diminta atau tidak diminta. (2) Dalam realitas sosial memiliki respons dalam menghadapi konflik sosial. Respons yang diberlakukan para ulama dipaparkan menjadi tiga hal antara lain, berupaya sebagai pelopor perdamaian saat terjadi kerusuhan, memberikan advokasi sosial dalam bentuk aksi dan menjadi mediator konflik saat muncul perselisihan
\end{abstract}

Kata Kunci: MUI, Kehidupan dan Keagamaan 
INJECT: Interdisciplinary Journal of Communication, Vol.2, No.1, Juni 2017: h. 141-160

\section{Pendahuluan}

Majelis Ulama Indonesia (MUI) didefinisikan sebagai organisasi yang di dalamnya terhimpun perwakilan para ulama dan cendikiawan muslim. Majelis Ulama Indonesia (MUI) didirikan bertujuan untuk mewadai semua persoalan umat Islam dan menjadi jembatan umat Islam dengan pemerintah. Sistem kepengurusan Majelis Ulama Indonesia (MUI) Surakarta di antaranya adalah ulama yang diambil dari organisasi Muhammadiyah, Sarekat Islam (SI), Nahdlatul Ulama (NU), Al-Islam, Majelis Tafsir al-Qur'an, dan As-Salam (Hudan,2014:115). Pada sisi yang lain, sejarah awal sebelum lahir Majelis Ulama Indonesia (MUI), terlebih dahulu berdiri Majelis Ulama (MU) di Surakarta. Status Majelis Ulama (MU) masih berdiri sendiri tanpa berafiliasi dengan Majelis Ulama Indonesia (MUI), selanjutnya masih berstatus sebagai wadah ulama lokal di Surakarta.

Peranan ulama dan pergerakannya di Nusantara (baca: Indonesia) seperti yang diceritakan dalam catatan sejarah terlihat begitu menonjol. Sebagaimana pada abad ke XVIII terjadi upaya pembaharuan dan revitalisasi ajaran Islam yang digerakkan oleh para ulama. Nama para ulama di Indonesia diantaranya, Nur Al-Din Al-Raniri, Abd Al-Ra'uf Al-Singkli, Muhammad Yusuf Al-Maqasari, dan Al-Palimbani. Mereka mengangkat tema pokok pembaharuan tentang "rekontruksi sosial-moral masyarakatmasyarakat muslim (Azra,1998:16)". Para ulama juga memiliki peran penting dalam proses transmisi interlektual-keagamaan dari pusat keilmuan Islam dari Makah dan Madinah ke Nusantara.

Selain memiliki peran besar dalam proses pembaharuan dan transmisi interlektual-keagamaan, pada abad IXX ditandai dengan adanya upaya perlawanan ulama terhadap penjajahan sebagaimana terjadinya perang Jawa (Diponegoro) dan perang Padri (Mufrodi,1994:4). Di Surakarta, kiai yang berperan dalam perang ini adalah kiai Muhammad Idris yang merupakan ulama penghulu dari keraton Kasunanan Surakarta. 
Dalam perang Diponegoro pondok pesantren Jamsaren digunakan oleh para ulama sebagai markas pergerakan. Ulama memiliki peranan dalam mengusir penjajah yang disebabkan atas kesewenang-wenangan bangsa kolonial terhadap masyarakat Jawa. Kuatnya cengkraman imperialisme tidak mampu dilawan dengan upaya yang dilakukan ulama, khususnya di Surakarta.

Perubahan pergerakan terlihat pada abad XX, ulama sangat berperan aktif dalam mengusir penjajah yang datang dari bangsa Belanda. Pada masa ini ditandai dengan munculnya ide-ide baru tentang keagamaan, sosial dan pendidikan yang dilakukan oleh tokoh-tokoh baik secara perorangan maupun kelompok. Para ulama aktif dalam bidang sosial-politik dan kemasyarakatan untuk mencapai kemerdekaan (Deliar,1980:37). Pada tahun 1911 di Surakarta, ditandai dengan berdirinya Sarekat Dagang Islam (SDI) yang didirikan oleh Haji Samanhudi sebagai suatu koperasi pedagang batik anti cina. Pada tahun 1912 organisasi tersebut merubah namanya menjadi Sarekat Islam (SI) di bawah kepemimpinan H.O.S Tjokroaminoto. Pada sisi yang lain, Muhammadiyah berdiri pada tahun 1923 dengan misi memperbaharui Islam dan menentang usaha-usaha kristenisasi yang dilakukan oleh kaum misionaris barat di Surakarta. Muhammadiyah mencurahkan kegiatannya dalam usaha-usaha pendidikan serta kesejahteraan dan program dakwah guna membendung perkembangan agama Kristen dan budaya lokal.

Pada waktu itu, SI dan Muhammadiyah berperan sebagai partner perjuangan, SI bergerak dalam bidang politik, sedangkan Muhammadiyah bergerak dalam bidang pendidikan dan dakwah. Perkembangan kedua organisasi ini tidak terlepas dari peran ulama sebagai aktor penggeraknya. Selanjutnya, hubungan sosial-politik para ulama dengan pemerintah pasca kemerdekaan (1945) berubah menjadi pola kompromistik-akomodatif. Hubungan yang ditampilkan adalah adanya proses kerjasama antara para ulama dengan pemerintah yang berkuasa. 
Berdasarkan uraian di atas terlihat bahwa muncul perubahan peranan yang dilakukan ulama, khususnya di Surakarta. Hal ini sangat lazim terjadi dalam tulisan sejarah, karena suatu proses sejarah pada dasarnya adalah proses perubahan (Dudung,2011:32). Dalam tulisan sejarah kontemporer di Indonesia, terjadi orientasi perubahan yang dilakukan oleh ulama. Pasca kemerdekaan, peran ulama di Indonesia mengalami dinamika yang cukup kompleks. Perubahan pemerintahan dari Orde Lama menjadi Orde Baru membuat para ulama menampilkan bentuk gerakan yang berkembang dan mengalami perubahan.

Dinamika pergerakan ulama pasca kemerdekaan, terutama ketika dipimpin oleh Presiden Soeharto berubah menjadi begitu mendasar. Hal ini berlanjut hingga berakhirnya masa pemerintahan Presiden Soeharto dan berlanjut pada masa reformasi. Pergerakan ulama dapat dilacak pasca didirikannya institusi sosial yang bernama Majelis Ulama Indonesia (MUI). Pada tahun 1975, Majelis Ulama Indonesia (MUI) didirkan dengan izin pemerintahan Orde Baru, hal ini berbeda dengan demokrasi terpimpin pergerakan umat Islam sangat dibatasi oleh pemerintah. Ditegaskan bahwa didirikan Majelis Ulama Indonesia (MUI) atas rekomendasi pemerintah Orde Baru bertujuan sebagai wadah persatuan umat Islam dan penghubung umat Islam dengan pemerintah. Tapi pergerakan Majelis Ulama Indonesia di awalnya masih dalam pengaruh pemerintah Orde Baru. Berangkat dari hal tersebut, peran Majelis Ulama Indonesia (MUI) sudah nampak untuk melakukan gerakan-gerakan sosial-keagamaan. Kepemimpinan Majelis Ulama Indonesia (MUI) yang pertama kalinya dijabat oleh Hamka. Pada dasarnya perubahan aktivitas ulama pasca kemerdekaan terutama pada masa Orde Baru (1975) sudah nampak ada upaya kompromistik dan kerjasama dengan pemerintah. Meskipun perjalanan Majelis Ulama Indonesia (MUI) di Indonesia mengalami dinamika yang selalu berubah. 
Perkembangan Majelis Ulama Indonesia di daerah-daerah membuktikan bahwa eksistensinya mengalami bentuk perkembangan, khususnya Majelis Ulama Indonesia di Surakarta. Hal yang menarik dalam penelitian ini yaitu menjadikan kota Surakarta sebagai objek studi, diperlihatkan dari dinamika sosial-keagamaan yang berbeda dengan daerah lain. Sisi-sisi unik kota Surakarta antara lain tentang tumbuh berkembangnya ideologi komunisme, adanya beragam corak pemikiran Islam dan adanya pelbagai macam organisasi massa Islam di Surakarta. Tidak menutup kemungkinan menjadikan peran Majelis Ulama Indonesia (MUI) Surakarta begitu dinamis dalam merespons fenomena sosial-keagamaan yang muncul di masyarakat.

Menurut KH. Muhammad Amir, di Surakarta terdapat beberapa organisasi atau kelompok lokal Islam yang tumbuh subur sepanjang sejarah yakni: Muhammadiyah, Al-Islam, Majelis Tafsir Al-Qur'an (MTA), Nahdlatul Ulama, Dewan Dakwah Islam Indonesia (DDII), Hitbutz Tahrir Indonesia (HTI), Front Pembela Islam (FPI), Persatuan Islam (PERSIS), Majelis Tabligh, Salafiyah, Pondok Al-Mukmin (Ngruki), Pondok Gumuk, Al-Irsyad, Diponegoro' Lembaga Dakwah Islam Indonesia (LDII).

Adanya beragam organisasi Islam yang tumbuh subur di Surakarta, melahirkan dinamika sosial-keagamaan yang menarik. Keunikan fenomena sosial-keagamaan di Surakarta menjadi daya tarik ilmiah sehingga cocok menjadi lokasi penelitian akademis. Respons Majelis Ulama Indonesia (MUI) Surakarta dalam menanggapi isu-isu dan fenomena sosial-keagamaan menjadi kajian yang unik. Aktivitas Majelis Ulama Indonesia (MUI) Surakarta kaitannya dengan dinamika sosial-keagamaan dalam merespons isu-isu yang berkembang di masyarakat menjadi sangat intensif. Maka berangkat dari asumsi tersebut melahirkan ide pokok dalam mengambil langkah penelitian dengan objek Majelis Ulama Indonesia (MUI) Surakarta adalah sangat problem oriented. 
INJECT: Interdisciplinary Journal of Communication, Vol.2, No.1, Juni 2017: h. 141-160

\section{Permasalahan}

Fokus permasalahan penelitian ini adalah kajian terhadap bentuk aktivitas Majelis Ulama Indonesia (MUI) berdasarkan perubahan atau perkembangan realitas sosial-keagamaan di Surakarta.

\section{Sosial-Keagamaan}

Majelis Ulama Indonesia (MUI) dapat dikategorisasikan sebagai sebuah organisasi sosial, insitusi sosial dan strukutur sosial dalam tatanan masyarakat. Sebagaimana dalam istilah sosiologi, Durkheim mengutamakan arti penting masyarakat (struktur, interaksi dan insitusi sosial) dalam memahami pemikiran dan perilaku manusia (Daniel,2012:129). Sebagai sebuah institusi sosial, Majelis Ulama Indonesia (MUI) dikategorisasikan sebagai sebuah organisasi sosial yang tidak lebih sebagai kumpulan orang-orang terpisah yang kebetulan berkumpul pada satu tempat dengan berbagai kepentingan(Daniel,2012:130). Maka dalam sebuah perkumpulan, Majelis Ulama Indonesia (MUI) sama halnya dengan institusi sosial yang lain seperti sebuah keluarga, sebuah desa, gereja, organisasi petani, dan organisasi buruh

Persepsi umum tentang Majelis Ulama Indonesia (MUI) adalah dipandang sebagai sebuah organisasi sosial serta institusi sosial. Definisi organisasi, seperti yang dikatakan Etsioni adalah unit sosial atau kelompok yang secara sadar mengkontruksi dan merekontruksi dalam mencapai tujuan (Emitai,1964:2). Sedangkan menurut March dan Simon, organisasi adalah sekelompok manusia yang berinteraksi dalam kelompok yang besar mereka memiliki sistem koordinasi, spesifikasi yang jelas dalam struktur dan koordinasi (March,1958:5). Sedangkan persepsi khusus tentang Majelis Ulama Indonesia (MUI) adalah kumpulan dari orang-orang yang disebut sebagai ulama.

Wujud individualistik Majelis Ulama Indonesia (MUI) dapat dianalisis dari personal ulama yang kemudian terhimpun di dalam institusi 
sosial atau organisasi. Pemahaman khusus tentang istilah ulama adalah bentuk jamak dari 'alim yang merupakan bentuk mubalaqah, yang berarti orang yang dalam pengetahuannya (Manzur,tt:310). Ulama menurut arti istilah ialah seseorang yang ahli dalam ilmu agama Islam dan mempunyai integritas kepribadian yang tinggi dan mulia serta berakhlak karimah dan berpengaruh di dalam masyarakat (Ulum,tt:1). Ulama dalam arti sosiologis dikategorikan sebagai pelaku atau orang, maka ia bukan hanya individu an sich, tetapi selalu dimiliki oleh sesuatu yang lain seperti: orang tua, sanak saudara, kota, suku, partai politik, tradisi etnis atau kelompokkelompok lainnya (Daniel,2012:130).

Berdasarkan uraian di atas, ulama bukan hanya dipahami secara individualistik bahwa ia adalah seseorang yang memiliki pengetahuan yang luas. Durkheim menyebut hal itu sebagai fakta individu. Sedangkan upaya kolektifitas, penghimpunan dan kumpulan para ulama dalam sebuah institusi sosial inilah yang disebut sebagai fakta sosial. Sebab semua kebutuhan manusia akan selalu terikat kepada komunitasnya. Durkheim lebih jauh mengatakan bahwa fakta sosial jauh lebih fundamental dibandingkan dengan fakta individu (Daniel,2012:130). Dalam hal itu juga harus menjelaskan individu melalui masyarakat dan menerangkan masyarakat dalam hubungan sosial.

Bentuk sosial-keagamaan seperti yang ditunjukkan oleh Majelis Ulama Indonesia (MUI) di Surakarta pada tahun 1970-an khususnya, dihadapkan dengan fenomena kehidupan masyarakat perkotaan. Perubahan sosial dalam masyarakat kota pada masa kolonialisme diwujudkan dengan perlawanan kaum terdidik dan kelas menengah. Karakteristik masyarakat kota dalam aspek transformasi sosial bercirikan adanya industrialisasi dan urbanisasi(Kuntowojoyo,2004:66). Selain itu, sudah beragam sekali kegiatan-kegiatan sosial masyarakat kota seperti: kegiatan domestik, agama, rekreasi, ekonomis, politik, kultural, dan hubungan antara warga secara struktural antara lembaga-lembaga masyarakat, hubungan kate- 
gorial antara kelompok-kelompok etnis, status dan kelas, dan bahkan hubungan personal antara sesama warga kota (Kuntowojoyo,2004:66). Transformasi sosial di Surakarta sudah bergeser ke sistem perkotaan dengan masuknya unsur-unsur budaya modern. Upaya kolektif dari ulama-ulama yang terhimpun ke dalam Majelis Ulama Indonesia (MUI) berusaha merespons fenomena sosial-keagamaan yang muncul. Peran sosial atau tanggung jawab sosial-keagamaan menjadi konsep dasar yang menggerakan Majelis Ulama Indonesia (MUI) berkiprah dalam kehidupan masyarakat di Surakarta.

Paradigma yang bisa dibangun di sini bahwa Majelis Ulama Indonesia (MUI) memiliki peran sosial, tanggung jawab sosial dan respons sosial terhadap kepentingan-kepentingan institusi sosial atau organisasi dalam perkembangan kehidupan sosial-keagamaan di Surakarta. Penjelasan teoritis bahwa ulama memiliki peran sosial adalah seperti digambarkan dalam jaringan ulama internasional abad 17 dan 18 Masehi. Peran ulama dalam jaringan tersebut ialah menitik beratkan pada pola-pola pembaharuan dan merevitalisasi ajaran-ajaran Islam. Disinilah peran ulama menjadi transmitter utama tradisi intelektual-keagamaan tradisi Islam dari pusat-pusat keilmuan Islam di Timur Tengah ke Nusantara (Azra,tt:16).

\section{Majelis Ulama Indonesia (MUI)}

Karakteristik sosial sebagaimana uraian di atas melahirkan konsepkonsep yaitu tentang aktivitas sosial Majelis Ulama Indonesia (MUI) di Surakarta yang dapat berbentuk peran, respons dan tanggung jawab sosial dalam menjalankan sistem organisasi di masyarakat. Terkait dengan hal itu maka adanya hubungan Majelis Ulama Indonesia (MUI) dengan institusi sosial lain (organisasi, partai politik, kelompok sosial, dll) dan masyarakat dapat disebut sebagai aktivitas sosial-keagamaan. Majelis Ulama Indonesia (MUI) sebagai sebuah organisasi menjalankan fungsi- 
nya untuk berdialog dengan realitas sosial-keagamaan dalam kehidupan masyarakat. Faktor yang mendukung hal tersebut adalah Majelis Ulama Indonesia (MUI) sebagai organisasi sosial-keagamaan memiliki peran sebagai mediator konflik, melakukan aktivitas sosial-keagamaan, dan menjalin hubungan dengan institusi sosial lainnya.

Perihal utama yang dijadikan pertimbangan teoritis tentang aktifitas sosial-keagamaan Majelis Ulama Indonesia (MUI) adalah peran sosial sebagai sebuah institusi sosial. Peran sosial-keagamaan Majelis Ulama Indonesia (MUI) diperlihatkan dari sistem sosial Majelis Ulama Indonesia (MUI) yang di dalamnya hal-hal mendasar tentang struktur organisasi, hubungan atau interaksi sosial, fungsi sosial yang dapat berdialog dengan sistem sosial di luar Majelis Ulama Indonesia (MUI). Konsep tentang aktivitas Majelis Ulama Indonesia (MUI) (interaksi, dialog dan hubungan) Surakarta dengan realitas sosial-keagamaan luar merupakan kajian penting penelitian ini.

Cara pandang terhadap Majelis Ulama Indonesia (MUI) yang individualistik oleh seorang peneliti tentunya mengarah kepada personal ulama. Dalam mengungkap fakta sosial, terlebih lagi jika ingin mengungkap fakta sosial-keagamaan maka dimensi kolektifitas ulama lah yang harus menjadi pusat perhatian. Majelis Ulama Indonesia (MUI) yang dikategorisasikan sebagai sebuah pranata sosial dan di dalamnya terhimpun ulama-ulama yang berinterasi. Konsep fakta sosial dalam kerangka teoritis Durheim, lebih mengutamakan hasil interaksi ulama sebagai realitas sosial yang kuat. Dibandingkan dengan analisis perilaku individu ulama dalam mengungkap bagaimanakah fakta sosial yang terjadi. Seperti yang dicontohkan oleh Dudung bahwa karya sejarah sosial itu sendiri identik dengan sejarah berbagai pergerakan sosial, misalnya, gerakan petani, gerakan protes, gerakan keagamaan, gerakan kebangsaan dan gerakan aliran ideologi atau politik (Dudung,2001:12). 
Karakteristik Majelis Ulama Indonesia (MUI) sebagai wadah interaksi para ulama mengandung konsep sosiologis tersendiri. Analisis sosiologis terhadap Majelis Ulama Indonesia (MUI) dapat dipahami sebagai sebuah golongan yang berperan dalam masyarakat. Hubungan sosial dan peran Majelis Ulama Indonesia (MUI) dalam merespons fenomena sosial-keagamaan menjadi kajian sosiologis tersendiri. Sedangkan perspektif sosial-keagamaan yang di tunjukkan oleh Majelis Ulama Indonesia (MUI) di Surakarta dipertegas oleh adanya interaksi pemikiran para ulama. Selanjutnya, proses sosial-keagamaan yang lebih luas dilakukan oleh Majelis Ulama Indonesia (MUI) adalah implementasi produk pemikiran dalam merespons realitas kehidupan masyarakat Surakarta.

Pengembangan pembahasan tentang aktivitas Majelis Ulama Indonesia (MUI) dalam penelitian ini akan menggunakan pendekatan behaviorisme. Ilmuan George Herbert Mead menggunakan analisis behaviorisme sosial sebagai sebuah pisau analisis penelitian sosiologi. Kajian Mead adalah ia berupaya mengembangkan ilmu pengetahuan empiris behaviorisme terhadap fenomena, yakni terhadap apa yang terjadi antara adanya stimulus dan respons (George,2004:268). Pemikiran Mead ini disebut juga sebagai teori interaksi simbolik yang menyatakan bahwa interaksi sosial sama dengan interaksi simbol.

\section{Interaksi Sosial Keagamaan}

Majelis Ulama Indonesia (MUI) memiliki peran dan posisi cukup sentral ditengah keberagaman corak pemikiran Islam di Indonesia. Rancangan sejarah (setting historis) dari dibentuknya Majelis Ulama Indonesia (MUI) adalah menjalankan peran mediator organisasi-organisasi Islam. Konsep mediator dapat dianalisis berdasar kerangka teoritis dalam pendekatan ilmu sosiologi. Mediator dapat di definisikan sebagai orangorang atau kelompok yang menempati posisi penghubung dan perantara antara dan sistem nasional yang bercorak perkotaan(Dudung,2011:156). 
Konsep mediator ini sangat penting diperankan oleh institusi sosial dalam menghadapi fenomena sosial-keagamaan yang muncul. Dalam perspektif sosial-politik misalnya muncul istilah konflik antar institusi atau golongan berkepentingan. Peran mediator dalam meredam potensi konflik yang lebih besar akan sangat penting di lakukan, dalam hal ini diembah oleh Majelis Ulama Indonesia (MUI).

Aktivitas Majelis Ulama Indonesia (MUI) Surakarta dalam rentang waktu 1975-2015 tentu berjumpa dengan perubahan sosial-keagamaan di masyarakat. Definisi operasional dalam aspek sosial-keagamaan dapat di identifikasikan seperti kondisi struktur sosial, pola pemikiran organisasi sosial, pola hubungan antar kelompok di dalam masyarakat yang bersangkutan (Dudung,2011:156), yang merupakan faktor dominan atas perubahan aktivitas gerakan Majelis Ulama Indonesia (MUI) Surakarta, sehingga dapat dianalisis pola gerak sejarah perkembangan kehidupan sosial-keagamaan di Surakarta yang dikategorisasikan sebagai daerah perkotaan.

Analisis sejarah perkotaan dalam aspek perkembangan dan polapola kehidupan masyarakat kota dengan konsep modernisasinya akan memberikan landasan teoritis dalam proses penelitian. Maka merujuk kepada analisis perubahan sosial yang dikembangkan oleh Kuntowijoyo tentang perubahan atau perkembangan, penelitian ini menggunakan model Marx. Perubahan dalam model Marx, secara umum melihat perkembangan masyarakat itu bergantung pada sistem ekonomi dan mengandung konflik-konflik sosial yang mengakibatkan timbulnya krisis, revolusi, dan perubahan yang terputus-putus (Dudung,2011:50).

Selanjutnya, mekanisme perubahan model Marx menekankan kepada aspek dialektika. Diasumsikan bahwa model Marx dijadikan sebagai alat analisis dalam aktivitas Majelis Ulama Indonesia (MUI) di Surakarta. Bahwa terjadi proses perubahan pada Majelis Ulama Indonesia (MUI) setelah melakukan interaksi serta hubungan dengan pihak luar. 
Bisa dengan institusi sosial lain ataupun dengan masyarakat secara luas. Maka dengan begitu akan muncul konsep sintesis di dalam proses dialektika tersebut. Jadi asumsi model Marx ini sebagai dasar perubahan di dalam tubuh Majelis Ulama Indonesia (MUI) Surakarta setelah menjalin hubungan dengan fenomena yang datang dari luar(Dudung,2011:51). Misalnya konsep modernisasi yang juga pernah dikembangkan oleh Weber dalam proses perubahan sosial. Analisis dialektika model Marx akan melahirkan sebuah respons atau tesis baru dalam menanggapi fenomena modernisasi. Modernisasi dan dampaknya dalam masyarakat menjadi pembahasan yang menarik seperti yang pernah dikembangkan oleh Weber. Pada dasarya aktivitas Majelis Ulama Indonesia (MUI) akan mengalami perubahan dan perkembangan seiring dengan fenomenafenomena yang datang dari pihak luar

\section{Metode Penelitian}

Penelitian ini dikembangkan dengan menggunakan pendekatan sejarah sosial yang merujuk kepada peristiwa atau realitas sosialkeagamaan di masyarakat. Sebagaimana manfaat dari pendekatan sejarah sosial adalah ingin mengungkap aktivitas sebuah organisasi masyarakat dalam merespons, berinteraksi, dan beraktivitas di dalam lingkungan sosial.

Berdasar kepada metodologi atau pendekatan tersebut, penelitian ini menggunakan kerangka teoritis yang merujuk terhadap beberapa konsep-konsep: Sosial-Keagamaan, Majelis Ulama Indonesia (MUI), dan Interaksi Sosial-Keagamaan. Kerangka konseptual di atas akan diuraikan agar dapat memberikan sebuah pengertian serta memperjelas mengenai gejala-gejala sejarah yang timbul dari aktivitas sebuah organisasi keagamaan. Dari situlah akan muncul beberapa penafsiran yang berdasar pada teori-teori untuk mengungkap dan menemukan bentuk-bentuk aktivitas sosial sebuah organisasi. 


\section{Penggerak Kehidupan Sosial-Keagamaan}

Majelis Ulama Indonesia (MUI) Surakarta berperan penuh terutama dalam lingkungan masyarakat Islam. Peranan utamanya memberikan anjuran, nasehat dan bimbingan fatwa baik diminta atau tidak diminta. Seiring dengan eksistensinya, aktivitas sosial keagamaan berwujud dalam bentuk yang lebih luas. Ulama Surakarta memerakan kelembagaannya sebagai wadah gerakan sosial. Selanjutnya, gerakan sosial diwujudkan dengan berbagai macam bentuk kegiatan ulama meliputi program-program keorganisasian.

Peranannya yang strategis di dalam masyarakat tidak menjauhkan hubungan Majelis Ulama Indonesia (MUI) Surakarta dengan organisasi Islam sebagai partner pergerakan. Organisasi Islam sebagai partner yang dimaksud antar lain Muhammadiyah, Nahdlotul Ulama, AlIrsyad, Dewan Dakwah Islam Indonesia (DDII), SI, Al-Islam, Ikatan Cendikiawan Islam Indonesia (ICMI), dan organisasi masa Islam lainnya. Sebagai wadah musyawarah umat Islam, Majelis Ulama Indonesia (MUI) Surakarta berusaha mensinergikan berbagai macam pikiran umat Islam tesebut. Dalam mewujudkan peranannya, para pengurus Majelis Ulama Indonesia (MUI) Surakarta sering bertemu dengan cendikiawan muslim, selanjutnya diakhiri dengan kegiatan konsultasi. Fenomena ini sebagai fase pergerakan awal ulama Surakarta pasca berakhirnya tantangan komunisme. Lebih tepatnya pada tahun 1975, saat era pemerintahan Orde Baru menuntut ulama terlibat dalam proses pembangunan. Di Surakarta, perluasan peran Majelis Ulama Indonesia (MUI) diwujudkan dengan berbagai aktivitas sebagai sebuah bentuk tindakan sosial. (1) Diskusi dengan Cendikiawan Muslim yaitu para ulama Surakarta memiliki kepedulian terhadap umat Islam dan sering dibahas bersama tokoh cendikiawan muslim. Masalah utama yang mereka diskusikan meliputi faktor keagamaan dengan konteks kepedulian terhadap kaum dhuafa'. Para ulama dan cendikiawan muslim menganggap persoalan kaum 
dhuafa' sebagai bagian umat Islam yang harus diselamatkan. Sebaliknya, kegiatan-kegiatan yang bertemakan menyantuni kaum dhuafa', menurut para ulama sangat potensial dalam menumbuhkan sikap kepedulian terhadap umat Islam. (2) Silaturahmi dengan Organisasi Islam; Pada awalnya, Majelis Ulama Indonesia (MUI) dikenal sebagai organisasi pemberi fatwa. Disisi yang lain, peranan Majelis Ulama Indonesia (MUI) juga dikhususkan sebagai wadah bagi organisasi masa Islam untuk bermusywarah. Di Surakarta, Majelis Ulama Indonesia (MUI) Surakarta diperankan sebagai wadah komunikasi umat yang tergabung dalam organisasi Islam untuk bermusyawarah. Pada awal tahun 1980, saat fase konsolidasi dilakukan oleh para ulama yang tergabung dalam Majelis Ulama Indonesia (MUI) Surakarta. Hal ini disebabkan dari perlunya sikap persatuan masyarakat Islam di Surakarta. Pergerakan awal yang dilakukan oleh Majelis Ulama Indonesia (MUI) Surakarta adalah dengan melakukan kegiatan silaturahmi kepada seluruh ormas Islam di Surakarta. Seperti dengan Muhammadiyah, Nahdlotul Ulama (NU), Ikatan Cendikiawan Muslim Indonesia (ICMI), Sarekat Islam (SI) dan Dewan Dakwah Islam Indonesia (DDII). Silaturahmi dilangsungkan dengan rutin, selanjutnya menyertakan kegiatan diskusi tentang masalah-masalah keumatan di Surakarta. Atas anjuran Ikatan Cendikiawan Muslim Indonesia (ICMI), mulai tahun 1982, para ulama diminta untuk memperhatikan nasib umat Islam dari semua sisi. Posisi Majelis Ulama Indonesia (MUI) Surakarta sebagai jembatan komunikasi umat Islam sangat sesuai. Terlebih lagi jika melihat struktur organisasi, terlihat susunan pengurusnya terdiri dari beberapa organisasi Islam di Surakarta. Perwakilan kiai dan ulama dari organisasi masa Islam di dalamnya, terjadi keselarasan dan komunikasi yang baik antar umat. Pengurus Majelis Ulama Indonesia (MUI) Surakarta terdiri dari perwakilan ulama organisasi Islam seperti Muhammadiyah, Al-Islam Majelis Tafsir Al-Qur'an (MTA), Nahdlotul Ulama (NU), AlIrsyad Sarekat Islam (SI), dan sebagainya. Seluruh organisasi Islam di Surakarta merupakan anggota Majelis Ulama Indonesia (MUI), kecuali 
Lembaga Dakwah Islam Indonesia (LDII). (3) Pelopor Kerukunan Antar Umat Beragama; hubungan antara para ulama yang tergabung di dalam Majelis Ulama Indonesia (MUI) Surakarta dengan kelompok beragama lain terjalin sangat baik. Islam sebagai mayoritas di Surakarta mampu menciptakan perdamaian antar pemeluk umat beragama. Pada tahun 2007, diperlengkap dengan berdirinya Forum Komunikasi Antar Umat Beragama (FKUB) di Surakarta. Jumlah anggota forum ini adalah 16 orang dan diantaranya 11 orang dari umat Islam karena sebagai mayoritas. Perana Majelis Ulama Indonesia (MUI) Surakarta dalam hal ini adalah sebagai penentu 11 orang yang diusulkan untuk menjabat sebagai pengusus Forum Komunikasi Antar Umat Beragama (FKUB) di Surakarta.

\section{Pelopor Perdamaian dan Konflik Sosial}

Interaksi Majelis Ulama Indonesia (MUI) Surakarta dengan realitas sosial memiliki respons dalam menghadapi konflik sosial. Respons yang diberlakukan para ulama dipaparkan menjadi tiga hal antara lain, berupaya sebagai pelopor perdamaian saat terjadi kerusuhan. Selanjutnya, memberikan advokasi sosial dalam bentuk aksi dan menjadi mediator konflik saat muncul perselisihan. Beberapa hal di atas merupakan sebuah upaya yang dilakukan oleh Majelis Ulama Indonesia (MUI) Surakarta dan dipahami sebagai respons sosial. Terjadinya konflik sangat tidak diinginkan para ulama, sebab sangat bertentangan dengan cita-cita Islam yang mengandung unsur kedamaian. Tiga hal sebagai bentuk respons para ulama jika terjadi konflik sosial adalah sebagai berikut. (1) Peristiwa Kerusuhan Tahun 1998; idealisme para ulama Surakarta yang menginginkan hadirnya kedamaian, keamanan dan harmonisasi sosial nampak dari jarang terjadi gejolak dan konflik sosial. Sejak berdirinya Majelis Ulama Indonesi (MUI) Surakarta, hampir tidak pernah ada konflik sosial antar umat Islam dan antar umat beragama. Kondisi ini merupakan kesesuaian antaraa ajaran Islam dengan idealisme pemikiran 
ulama dalam keharusan menjaga keharmonisan sosial, terutama di Kota Surakarta. Pandangan ini sangat penting disebabkan keragaman sosial yang meliputi kuantitias organisasi masa Islam dan keberadaan orang berbeda etnis dan agama. Kondisi keharmonisan dan kedamaian harus dijaga, dirawat dan dilestarikan. (2) Penutupan Lokalisasi Silir Pasar Kliwon; Kampung Silir, terletak di Kecamatan pasar Kliwon, sebuah daerah yang merupakan salah satu pusat perekomomian Kota Surakarta, Jawa Tengah. Kawasan ini adalah sebagai pasar besi, pasar ayam dan tempat penjualan barang-barang bekas (loak). Pada tahun 1997, kawasan ini digunakan sebagai pusat lokalisasi dan prostitusi. Lokasinya memiliki luas 3000 meter persegi, yang sudah berdiri sejak tahun 1960-an. Dampak ekonomi yang cukup menjanjikan melanda warga-warga yang tinggal di sekitar lokalisasi. Tepatnya pada tahun 1997, ketika pemerintahan Surakarta dipimpin oleh wali kota Imam Sutopo. Pertimbangan logisnya menurut KH. Dimyati penutupan lokalisasi ini dimaksudkan untuk meminamalisir penyakit yang berkembang di masyarakat, salah satunya adalah HIV/AIDS. Alasan lain adalah upaya pemerintah mengajak masyarakat untuk mencari rezeky yang halal tanpa menjual tubuhnya di tempat lokalisasi. Pemerintah mengajak mengangkat harkat dan martabat kaum perempuan untuk membekali dirinya dengan skill. Inilah menurut KH. Dimyati yang merupakan alasan mengapa lokalisasi Silir harus ditutup. (3) Bentrok Berdarah di Joyosuran ; konsep mediator terlihat dari aktivitas Majelis Ulama Indonesia sebagai penghubung jika terjadi konflik sosial di masyarakat konflik disini dipahami sebagai benturan sosial yang mengandung unsur negatif dalam tatanan sosial. Sebagaimana didirikannya Majelis Ulama Indonesia (MUI) Surakarta bertujuan untuk wadah bermusyawarah antar umat Islam. Diwakili oleh para ulama dalam kepengurusan yang telah menjadi anggota maupun pengurusnya. Kepeloporan Majelis Ulama Indonesia (MUI) Surakarta terhadap konflik sosial diwujudkan dalam beragam berbentuk. 


\section{Kemitraan Majelis Ulama Indonesia (MUI) dengan Pemerintah}

Majelis Ulama Indonesia (MUI) Surakarta menjalin interaksi dengan pemerintah dalam bentuk kerjasama sosial-keagamaan. Proses kerjasama yang dimaksud disini adalah hubungan yang terjalin antara Majelis Ulama Indonesia (MUI) Surakarta bersama dengan pemerintah. Kemitraan atau proses kerjasama tersebut dijelaskan dalam tiga hal, yaitu kemitraan dalam pembinaan umat Islam, komitmen dalam pemberantasan penyakit sosial, dan sosialisasi syari'at Islam yang melibatkan unsur pemerintahan. Ketiga hal tersebut dipahami sebagai bentuk kemitraan antara para ulama dengan pemerintah sebagai institusi yang bergerak di bidang sosial keagamaan di Surakarta. Sebagaimana peranan Majelis Ulama Indonesia (MUI) Surakarta sebagai wadah perjuangan ulama ditampilkan dengan kentalnya hubungan dengan masyarakat. Penjelasan ketiga hal ini dipaparkan dibawah ini sebagai berikut. (1) Pembinaan Umat Islam; sumbangan terpenting dari pergerakan Majelis Ulama Indonesia (MUI) di Surakarta bagi umat Islam adalah semangatnya dalam melakukan upaya pembinaan umat Islam. Gerakan para ulama Surakarta pasca berdirinya Majelis Ulama Indonesia (MUI) Surakarta mempengaruhi pola sosial, politik, ekonomi, kebudayaan, pendidikan dan keagamaan masyarakat Islam di Surakarta. Sikap dan penilaian orang terhadap Majelis Ulama Indonesia (MUI) Surakarta adlah dipandang ada kalanya seperti pemerintahan, dan adakalanya tampil seperti organisasi massa Islam yang lainnya, seperti Muhammadiyah, NU, AlIslam, Al-Irsyad, dan SI. Persepsi lain masyarakat tentang Majelis Ulama Indonesia (MUI) Surakarta adalah lembaga semi afisiel sehingga fungsi dan mekanisme kegiatannya tidak jauh dari instansi-instansi pemerintah.

(2) Pemberantasan Penyakit Sosial, Kemitraan ulama dengan umaro' (pemerintah), ditampilkan dengan bentuk aksi di dalam masyarakat. Mereka sangat kompak dan dapat menjalin komunikasi dengan sangatbaik. Usaha yang dilakukan ialah memiliki komitmen dalam pemberantasan 
penyakit sosial di masyarakat. Hal ini telah mereka lakukan dengan upaya penutupan lokalisasi tempat prostitusi di kampung Silir, Semanggi, Pasar Kliwon. Ulama mendorong pemerintah untuk mengeluarkan kebijakan penutupan lokalisasi Silir. (3) Partner Perjuangan dan Pemberdayaan Umat; Majelis Ulama Indonesia (MUI) Surakartaa bersama-sama dengan pemerintah menjadi media pergeraakan para ulama yang paling dominan di Surakarta. Peranannya adalah menumbuhkembangkan sikap peduli kepada nasib umat dengan semangat keislaman. Majelis Ulama Indonesia (MUI) Surakarta memiliki peran sebagai penterjemah timbal balik antara ulama, umara', zuama' dan berdiri sebagai payung umat Islam yang dapat mengayomi. Berbagai macam aksi dilakukan, terutama sebagai pelopor persatuan dan keharmonisan umat dan bangsa, khususnya di kota Surakarta. Cita-cita luhur diwujudkan bersama-sama antara ulama dan umaro' sebagai partner perjuangan dan pemberdayaam umat.

\section{Simpulan}

Hasil penelitian ini menemukan bahwa aktivitas Majelis Ulama Indonesia (MUI) Surakarta yakni: sebagai jembatan komunikasi antar umat, sebagai mediator terjadi konflik sosial dan memberikan anjuran, memberi nasehat dan bimbingan fatwa. Aktivitas Majelis Ulama Indonesia (MUI) Surakarta dalam masyarakat terdiri dari tiga hal, pertama yakni sebagai penggerak kehidupan sosial keagamaan. Dalam hal ini bahwa Majelis Ulama Indonesia (MUI) Surakarta sering melakukan diskusi dengan cendikiawan muslim. Kedua, Majelis Ulama Indonesia (MUI) Surakarta selalu melakukan silaturahmi dengan organisasi Islam. Ketiga, Majelis Ulama menjadi pelopor kerukunan antar umat beragama. Keempat, hubungan dengan LDII merupakan buah interaksi ulama Surakarta tersendiri. Kelima, MUI Surakarta dan ingkarus sunah. Selanjutnya, MUI Surakarta memiliki posisi yang penting di tengah-tengah masyarakat beragama di Surakarta. MUI diperankan sebagai organisasi penengah jika terjadi konflik sosial. Diantara konflik yang dimaksud adalah peristiwa 
kerusuhan 1998 di Surakarta, bentrok berdarah di Joyosuran dan gejolak sosial saat penutupan lokalisasi Silir. Disini Majelis Ulama Indonesia merespons kondisi itu sesuai dengan fungsinya sebagai mediator konflik sosial. Terakhir bahwa MUI memiliki hubungan kemitraan dengan pemerintah sebagai partner perjuangan dalam pembinaan umat Islam di Surakarta.

\section{Daftar Pustaka}

Ali Mufrodi. 1994. Peranan Ulama Dalam Masa Orde Baru: Study Tentang Perkembangan Majelis Ulama Indonesia. UIN Sunan Kalijaga: Program Pascasarjana.

Azyumardi Azra. 1998. Jaringan Ulama Timur Tengah dan Kepulauan Nusantara Abad XVII da XVIII. Bandung: Mizan.

Bahlu 'Ulum. Ulama dan Demokrasi; Studi Fatwa Golput MUI Era Reformasi.

Desertasi. UIN Sunan Kalijaga Program Pascasarjana.

Daniel L. Plas. 2012. Seven Theories Of Religion, Penerj. Inyiak Ridwan Munir. Yogyakarta: IRCiSoD.

Deliar Noer. 1980. Gerakan Modern Islam di Indonesia 1900-194.Jakarta. LP3ES.

Dudung Abdurahman. 2011. Metodologi Penelitian Sejarah Islam. Yogyakarta. Ombak.

Emitai and Etzioni. 1964. Social Change, Sources, Patterns and Consequence.

New York. London Basic Books Inc Publishers.

George Ritzer dan Douglas J. Goodman. 2004. Teori Sosiologi Modern. Jakarta Kencana. edisi ke enam.

Ibn Manzur Jamaluddin Muahmmad Ibn Mukkaran al-Ansari. Lisanul 'Arab jilid XV. ad Darul Misriyyah Lit Ta'lif wa-Tarjmah

J.G. March and H.A. Simon. 1958. Organizations. New York: John Wiley and Sons.

Kuntowijiyo. 2004Metodologi Sejarah. Yogyakarta Tiara Wacana Yogya 
INJECT: Interdisciplinary Journal of Communication, Vol.2, No.1, Juni 2017: h. 141-160

Nurul Hudan dan Fathurrohman Husein. 2014. Upaya MUI Surakarta Meningkatkan Animo Pengusaha Untuk Mendapatkan Rekomendasi Halal Surakarta: Jurnal UMS 